\title{
2. ジーンターゲティングによる行動異常の解析
}

\author{
八木 健 \\ 岡崎国立共同研究機構生理学研究所 高次神経機構部門 \\ Behaviral Abnormalities of Gene Targetted Mice \\ Takeshi YAGI \\ Laboratory of Neurobiology and Behavioral Genetics, \\ National Institute for Physiological Sciences
}

\begin{abstract}
Summary
Part of the behavior in mammalian species is genetically programmed, and gene targeting technology using embryonic stem cells provides a powerful tool for the molecular analysis of genes involved in such behavior. Here we present how behavioral alterations were produced by disruption of an endogenous Fyn tyrosine kinase. These results may indicate that mutant mice produced by the gene targeting are useful for molecular analyses in mammalian behaviors and supply of animal models for human diseases.
\end{abstract}

\section{緒言}

動物の行動が種物異性を持ち, 子孫に遺伝すること は，何らかの遗伝情報としてゲノム中に保存されてい ることを意味する.ヒトを含む哺乳動物においてもそ の例外ではない。近年，マウス泼性幹細胞を用いた遺 伝子ターゲティング法が確立され，今まで困難であっ た哺乳動物における遺伝子と行動との関連性の解析が 可能となってきた。我々はチロシンリン酸化酵素の Fynが，哺乳動物の行動制御に重要な役割を果たして いることを遺伝子欠損マウスの作製とその解析により 明らかにしてきた。

\section{実験材料}

我々は, 德永智之が $\mathrm{C} 57 \mathrm{BL} / 6$ と $\mathrm{CBA}$ の $\mathrm{F}_{1}$ 泼よ り樹立した TT-2 細胞を用いて遺伝子ターゲティング 法を行った1)。 また，生まれたキメラマウスはC57 BL/6 マウスとの掛け合わせによりへテロ Fyn 欠損 マウスを得，その掛け合わせによりホモ Fyn 欠損マ ウスを得た. 行動実験にはホモ欠損マウスとへテロ欠 損マウスとの掛け合わせにより同腹で得られたマウス を遺伝子鑑定をせずにブラインドテストを行い，行動 実験後に遺伝子鑑定をして統計処理を行った。

\section{方 法}

マウスゲノミックライブラリーより Fyn ゲノミッ ク DNA を得て, ターゲティングベクターを作製し た.ターゲティングベクター作製には Fyn の代わり
に $\beta$-ガラクトシダーゼが発現するように遺伝子構築 を行い, ポジティブ選別として neo 遺伝子, ネガテ ィブ選別として DT-A 遗伝子を用いた ${ }^{2,3)}$ ，TT-2 細 胞中にェレクトロポレーション法により制限酵素で線 状化したターゲティングベクターDNAを導入し， G418 による薬剤選別を行った。相同組み換え体はサ ザンブロッティング法と PCR 法により判定した. 得 られた相同組み換え体はマイクロインジェクション法 により 8 細胞胚に注入して, キメラマウスを作製し た. キメラ率の高い雄マウスを野生型マウスと交配す ることによりへテロ Fyn 欠損マウスを得た. マウス の飼育条件は始め 14 時間・10 時間 (明・暗), 北米 産のモミ材を $120^{\circ} \mathrm{C}, 30$ 分オートクレーブしたものを 床じきとして用いた。

\section{実験成績}

Fyn 欠損マウスを交配により得ることができた。 テロ遺伝子欠損マウスの $\beta$-ガラクトシダーゼ活性に よる発現様式の解析の結果, Fynは神経管形成, 神経 細胞分化, 神経突起伸長, ミェリン形成で特異的な発 現をしていることが明らかとなり，成体中枢神経系で は嗅球, 海馬, 小脳で特に高い発現が，また感覚神経 経路での特徴的な発現が認められた 4 6).

Fyn 欠損マウスは殆んど大きな異常が認められなか ったが，Fyn 欠損マウス同土を掛け合わせると，その 子孫マウスは殆ど母乳を飲めずに死亡した。この原因 
を解析するため野性型の雄と Fyn 欠損雌マウスを交 配させたところ，産まれてきだへラロ欠損仔マウスは 母乳を领んで正常に生育した．また，生まれた Fyn 欠損仔マウスを野生型雌マウスに育てさせると，正常 に発育した．これらのことより，仔マウスの死亡の原 因はFyn 欠損マウスの母親と仔両方の原因によりお こることが明らかとなった．仔側の異常を調べるため に母親の乳首に対する行動を観察したところ, Fyn 欠 損仔マウスは一度も吸われていない乳首を探す能力 が，正常の仔マウスに比べ劣っていることが明らかと なった7)。生後仔マウスが乳首を探す際には哺乳フェ ロモンが重要であることが知られており，Fyn 欠損、 ウスではこのフェロモンに対する感受性が減少してい ることが考兄られる.この可能性を探る目的で生後直 後の嗅感覚神経系での Fyn の発現を $\beta$-ガラクトシ ダーゼの活性により解析した結果, Fyn は嗅上皮, 鉫 鼻器の感覚神経で高発現していることが明らかとなっ た．また，嗅感覚の情報処理に重要に関わる嗅球にお。 いても高発現をしていることが明らかとなった。

また, Fyn 欠損マウス母親側の異常については出産 時の連続観察により, 産んだ仔マウスが引き離されて 行く哺育行動の異常, 羊膜・胎盤を処理しない等が観 察された.この異常は, 飼有環境に依存していること が最近明らかとなりつつある.

Fyn 欠損マウスは Grant 等により，海馬 CAl 領 域での高頻度刺激による長期增強の減少が認められ, モリス水迷路学習に拈ける空間学習の異常が報告され ている8). 我々の作製したFyn 欠損マウスにおいても マウス系統, 久損方法の湋いがあるにも関わらず同様 の空間学習の異常が認められた. しかし, モリス水迷 路学習と同样汇海馬依存的学習課題である八本迷路学 習を行ったところ Fyn 欠損マウスにおいても学習の 障害は認められなかった。 また, 受動的回避行動実験 による学習効果を観察した結果, Fyn 欠損マウスは野 生型マウスに比べてより学習が向上していることが明 らかとなった ${ }^{10)}$. 以上の結果より，Fyn 欠損マウスで は学習課題の違い, 即ち学習課題で用いられる動機付 けの違いにより学習行動障害に差があることが明らか となった. モりス水迷路学習課題の際に認められる学 習障害が Fyn 欠損マウスの学習過程での障害なのか については今後慎重に検討する必要がある.

我々はFyn 欠損マウスにおける哺育行動, モリス 水迷路での学習障害より Fyn 欠損マウスでの情動行 動異常の可能性を考え, 情動行動に関する行動実験を
行った。 その結果, Fyn 欠損マウスでは明るい場所を 嫌う, 新奇環境を嫌う等の情動行動での異常が明らか となっだ、. 環境のストレスに対する感受性の六進が 認められて打り，この結果は上記した Fyn 久損マウ スでの哺育行動，モリス水迷路での学習障害を考える 際, 情動行動の異常を考慮する必要があることを示唆 する結果として注目されるままた，情動行動と相関 関倸が指摘されている聴覚性㾏尜発作について, 最 近我々はFyn 欠損マウスで痙摹が起こりやすいこと を明らかにしており，Fyn の情動行動制御に拈ける分 子機構を考える際の興味深い結果として注目してい $ろ^{10)}$.

\section{総 括}

マウス肧幹細胞を用いた遺伝子ターゲティング法の 確立により，特定遺伝子欠損マウスの作製が可能とな った。この技術により我々の作製した Fyn 欠損マウ スでは, 哺乳, 学習, 情動行動に異常が明らかとなっ た.この結果は Fyn が哺乳動物の行動を制御する分 子の一つであることを示㖫する. 遺伝子ターゲティン グ法による行動制御の解析はまだ始まったばかりであ るが，今後分子メカニズム解明だけでなく，ヒト疾患 に関連する疾患モデル動物を産出して行く上でも重要 な方向性であると確信している.

\section{文 献}

1) Yagi, T., Tokunaga, T., Furuta, Y., Nada, S., Yoshida, M., Tsukada, T., Saga, Y., Takeda, N., Ikawa, Y. and Aizawa, S.: Anal. Biochem., 214, 70 (1993)

2) Yagi, T., Ikawa, Y., Yoshida, K., Shigetani, Y., Takeda, N., Mabuchi, I., Yamamoto, T. and Aizawa, S. : Proc. Natl. Acad. Sci. USA, 87, 9918 (1990)

3) Yagi, T., Nada, S., Watanabe, N., Tamemoto, H., Kohmura, N., Ikawa, Y. and Aizawa, S. : Anal. Biochem., 214, 77 (1993)

4) Yagi, T., Shigetani, Y., Okado, N., Tokunaga, T., Ikawa, Y. and Aizawa, S.: Oncogene, 8, 3343 (1993)

5) Yagi, T., Shigetani, Y., Furuta, Y., Nada, S., Okado, N., Ikawa, Y. and Aizawa, S.: Oncogene, 9, 2433 (1994)

6) Yagi, T., Aizawa, S., Tokunaga, T., Shigetani, Y., Takeda, N. and Ikawa, Y. : Nature, 366, 742 (1993)

7) Yagi, T. : Dev. Growth \& Differ., 36, 543 (1994)

8) Grant, S.G.N., O’Dell, T.J., Karl, K.A., 
Stein, P.L., Soriano, P. and Kandel, E.R.: Science, 258, 1903 (1992)

9) Miyakawa, T., Yagi, T., Watanabe, S. and
Niki, H. : Mol. Brain Res., 27, 179 (1994)

10) Miyakawa, T., Yagi, T., Taniguchi, M. and Niki, H. : Mol. Brain Res., 28, 349 (1995) 